Organometallics. 2016 September 12; 35(17): 2938-2943. doi:10.1021/acs.organomet.6b00487.

\title{
Synthesis and Properties of "Sandwich" Diimine-Coinage Metal Ethylene Complexes
}

\author{
Kristine Klimovica $^{\dagger}$, Kristin Kirschbaum $^{\ddagger}$, and Olafs Daugulis ${ }^{\star}, \dagger$ \\ tDepartment of Chemistry, University of Houston, Houston, Texas 77204-5003, United States \\ ¥Department of Chemistry, University of Toledo, Toledo, Ohio 43606, United States
}

\begin{abstract}
Synthesis and full characterization of cationic isostructural "sandwich" diimine-coinage metal ethylene complexes are reported. Ethylene self-exchange kinetics proceeds by an associative exchange mechanism for $\mathrm{Cu}$ and $\mathrm{Au}$ complexes. The fastest ligand exchange was observed for $\mathrm{Ag}$ complex 8a. The upper limit of $\Delta G^{\natural}$, assuming associative ligand exchange, was found to be ca. $5.0 \mathrm{kcal} / \mathrm{mol}$. Ethylene self-exchange in Cu complex $7 \mathrm{~b}$ proceeds with $\Delta G_{298}+12.9 \pm 0.1 \mathrm{kcal} /$ mol, while the exchange is the slowest in Au complex 9, with $\Delta G_{298}+16.7 \pm 0.1 \mathrm{kcal} / \mathrm{mol}$. Copper complex $\mathbf{7 b}$ is unusually stable and can survive in air for years.
\end{abstract}

\section{Graphical abstract}

Synthesis, characterization ligand exchange studies

$$
\begin{aligned}
& \mathrm{Ar}=3,5-\mathrm{Cl}_{2} \mathrm{C}_{6} \mathrm{H}_{3} \\
& \mathrm{M}=\mathrm{Cu}, \mathrm{Ag}, \text { and } \mathrm{Au}
\end{aligned}
$$

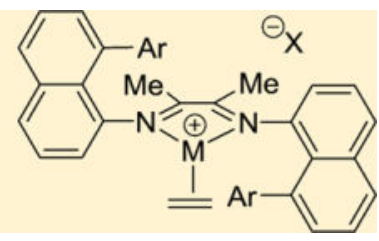

\section{INTRODUCTION}

Transition-metal-alkene complexes are important intermediates in catalysis. Many processes, such as olefin polymerization, hydrogenation, metathesis, and cyclopropanation, involve the intermediacy of metal-alkene complexes. ${ }^{1,2 a}$ The olefin complexes of group 11 metals are less common and become increasingly rare moving from copper to silver to gold despite their importance in cyclopropanation and carbon-hydrogen bond functionalization. ${ }^{2}$ In fact, the first gold-ethylene complex was structurally characterized only recently. ${ }^{3}$ Furthermore, direct comparison of all three coinage metal-ethylene complexes is difficult, as very few have been synthesized with analogous supporting ligands. ${ }^{4}$ Ligand exchange kinetic data

\footnotetext{
*Corresponding Author: (O. Daugulis): olafs@uh.edu. Supporting Information

The Supporting Information is available free of charge on the ACS Publications website at DOI: 10.1021/acs.organomet.6b00487. Detailed experimental procedures, kinetic calculations, and characterization data for new compounds (PDF) Crystallographic data (CIF)

Notes

The authors declare no competing financial interest.
} 
have not been obtained for isostructural group 11 metal olefin complexes. Moreover, few monomeric cationic coinage metal-ethylene complexes have been crystallographically characterized. ${ }^{4 a-e, 5}$

We have developed a general synthesis of 8-aryl-1-naphthylamines based on $\mathrm{C}-\mathrm{H}$ bond functionalization. ${ }^{6}$ In collabo ration with the Brookhart and Coates groups, palladium and nickel complexes of "sandwich" diimines derived from 8-aryl-1-naphthylamines were used for olefin polymerization (Figure 1). ${ }^{7}$ Interestingly, complex 2a catalyzes living polymerization of ethylene at room temperature. This was attributed to the increased axial steric bulk provided by the capping arene groups. ${ }^{7 \mathrm{~b}}$ Consistent with living polymerization and increased axial bulk, the rate of associative ethylene exchange in $\mathbf{2 b}$ is exceedingly slow compared to other palladium diimine systems. ${ }^{7 b}$

The axial aryl substituents on the ligand provide steric protection for the coordinated metal center and substantially retard associative ligand exchange. We speculated that coinage metal "sandwich" diimine complexes with ethylene should possess increased stability. We report here the synthesis, characterization, and ethylene exchange kinetics of "sandwich" diimine copper, silver, and gold complexes.

\section{SYNTHESIS OF COMPLEXES}

\section{A. Ligand Synthesis}

8-(3,5-Dichlorophenyl)naphthalen-1-amine was synthesized by using $\mathrm{C}-\mathrm{H}$ bond functionalization methodology developed earlier. ${ }^{6}$ The synthetic procedure is summarized in Scheme 1. Picolinic acid 1-naphthylamide was coupled with 3,5-dichloroiodobenzene to yield $N$-(8-(3,5-dichlorophenyl)-naphthalen-1-yl)picolinamide (4) in 77\% yield. The reaction is easily scalable and can be performed on at least an $80 \mathrm{mmol}$ scale. The reaction requires a $\mathrm{Pd}(\mathrm{OAc})_{2}$ catalyst, $\mathrm{AgOAc}$ as a base, and a halide removal agent and proceeds in the absence of solvent. Amide hydrolysis yields 8-(3,5-dichlorophenyl)naphthalen-1-amine (5). Synthesis of 2,3-butanedione diimine ligand 6 was accomplished in $86 \%$ yield.

\section{B. Synthesis and Properties of Copper Complexes 7a and 7b}

Treatment of a dichloromethane solution of ligand 6 with $(\mathrm{CuOTf})_{2} \mathrm{PhH}$ in the presence of ethylene afforded triflate $\mathbf{7 a}$ in $85 \%$ yield as a red solid (Scheme 2). The corresponding hexafluoroantimonate salt $7 \mathbf{b}$ was synthesized by the reaction of $\mathrm{Cu}\left(\mathrm{C}_{2} \mathrm{H}_{4}\right)_{3} \mathrm{SbF}_{6}{ }^{4 \mathrm{a}}$ with $\mathbf{6}$ in ethylene-saturated $\mathrm{CH}_{2} \mathrm{Cl}_{2}$. Complex $\mathbf{7 b}$ was obtained in $81 \%$ yield as an orange solid after crystallization by layering pentane over the solution of $7 \mathbf{b}$ in $\mathrm{CH}_{2} \mathrm{Cl}_{2}$ at $-20{ }^{\circ} \mathrm{C}$. Pure $7 \mathbf{a}$ and $\mathbf{7 b}$ are relatively stable and can be stored outside the glovebox at room temperature under an inert atmosphere for years without any signs of decomposition, as evident by ${ }^{1} \mathrm{H}$ NMR spectroscopy and single-crystal crystallography. Furthermore, solid $\mathbf{7 b}$ is stable if kept on the bench under air for years, and it does not lose complexed ethylene if kept under vacuum for at least $30 \mathrm{~min}$. The unusual stability of $\mathbf{7 a}$ and $\mathbf{7 b}$ relative to other known $\mathrm{Cu}$-ethylene complexes may be related to steric protection provided by the axially positioned aryl groups on the ligand. 
Complexes 7a and $7 \mathbf{b}$ were characterized by ${ }^{1} \mathrm{H}$ and ${ }^{13} \mathrm{C}$ NMR spectroscopy and elemental analysis. The ${ }^{1} \mathrm{H}$ NMR spectrum of $\mathbf{7 a}$ in $\mathrm{CDCl}_{3}$ shows a broad resonance centered at 4.01 $\mathrm{ppm}$ that is assigned to the signal of the ethylene ligand protons. In contrast, complex $\mathbf{7 b}$ shows two resolved signals for ethylene protons at 4.01-3.93 (m, 2H) and 3.86-3.77 ppm $(\mathrm{m}, 2 \mathrm{H})$ in $\mathrm{CD}_{2} \mathrm{Cl}_{2}$. A carbon-13 signal for complexed $\mathrm{C}_{2} \mathrm{H}_{4}$ was not observed in the ${ }^{13} \mathrm{C}$ NMR spectra of 7a from -20 to $+40{ }^{\circ} \mathrm{C}$. However, the shift for bound $\mathrm{C}_{2} \mathrm{H}_{4}$ can be located using 2D-HMQC NMR spectra, and it appears at $88.9 \mathrm{ppm}$. For $\mathbf{7 b}$, the bound ethylene signal in the ${ }^{13} \mathrm{C}$ spectrum appears at $88.0 \mathrm{ppm}$. The assignment of the signal was verified by 2D- HMQC NMR spectra. The complexed ethylene signals in the ${ }^{1} \mathrm{H}$ and ${ }^{13} \mathrm{C}$ spectra are substantially upfield compared with those of other monomeric cationic copper-ethylene complexes and are similar to shifts observed in neutral complexes. ${ }^{4 a, f, 5,8}$

Crystals of 7a suitable for X-ray analysis were grown by layering $\mathrm{Et}_{2} \mathrm{O}$ over the solution of the complex in $\mathrm{CH}_{2} \mathrm{Cl}_{2}$ at $-20{ }^{\circ} \mathrm{C}$. The ORTEP diagram of complex 7a is shown in Figure 2. The solid-state structure of $7 \mathbf{a}$ shows an ethylene ligand coordinated to copper in a typical $\eta^{2}$ fashion. Ethylene is nearly coplanar with the $a$-diimine ligand and the ligand chelates the copper ion with a bite angle of $81.94(16)^{\circ}$. The complexed ethylene $\mathrm{C}=\mathrm{C}$ distance is 1.346(8) $\AA$, which is slightly lengthened compared to the $\mathrm{C}=\mathrm{C}$ distance of free ethylene $(1.337 \AA)$ and is fairly typical for the values observed in other copper(I)-ethylene complexes with bidentate nitrogen- donating ligands. ${ }^{4 \mathrm{f}, 5} \mathrm{The} \mathrm{Cu}-\mathrm{C}$ (ethylene) distances for $\mathbf{7 a}$ are $1.972(5)$ and 2.016(5) $\AA$. The aryl groups of the ligand are centered over the five-membered chelate ring. Interestingly, the ortho-carbons of the dichlorophenyl groups (C22, C38) show a relatively close approach to $\mathrm{Cu}(1)$ at 3.17 and $3.14 \AA$.

\section{C. Synthesis and Properties of Silver Complexes $8 \mathrm{a}$ and $8 \mathrm{~b}$}

Silver-ethylene complexes are substantially rarer than the corresponding copper complexes, presumably due to their instability that is caused by the more oxidizing nature of $\mathrm{Ag}(\mathrm{I})$ and weaker binding of olefins to Ag. ${ }^{9}$ Reaction of $\mathrm{AgSbF}_{6}$ with ligand 6 in the presence of ethylene in $\mathrm{CH}_{2} \mathrm{Cl}_{2}$ at $-75^{\circ} \mathrm{C}$ afforded complex 8a as a dark orange, air-, temperature-, and light-sensitive solid (Scheme 3). It decomposes at room temperature within 1 day as a solid and within a few hours in solution under an inert atmosphere. It can be stored for several months as a solid under an inert atmosphere at $-20^{\circ} \mathrm{C}$. The corresponding tetrafluoroborate complex $\mathbf{8 b}$ was obtained similarly in $88 \%$ yield as an orange-brown, sensitive solid.

Complexes $8 \mathbf{a}$ and $8 \mathbf{b}$ were characterized by ${ }^{1} \mathrm{H}$ and ${ }^{13} \mathrm{C}$ NMR spectroscopy and elemental analysis. The signal of the ethylene ligand protons appears as a singlet at $4.94 \mathrm{ppm}$ in $\mathrm{CDCl}_{3}$ (8a) or $\mathrm{CD}_{2} \mathrm{Cl}_{2}(\mathbf{8 b})$ solvents. Carbon-13 signals for complexed $\mathrm{C}_{2} \mathrm{H}_{4}$ appear at $105.4(\mathbf{8 a})$ and $105.9(\mathbf{8 b}) \mathrm{ppm}$. The assignment of complexed ethylene ${ }^{13} \mathrm{C}$ signals was verified by DEPT-135 or 2D-HMQC experiments. The complexed ethylene signals in ${ }^{1} \mathrm{H}$ and ${ }^{13} \mathrm{C}$ spectra are shifted somewhat upfield compared with those observed for other monomeric cationic silver-ethylene adducts. ${ }^{4 a-c, f}$ However, the dearth of well-characterized cationic $\mathrm{Ag}$ complexes and their structural differences with $\mathbf{8}$ do not allow for meaningful comparisons.

Crystals of $\mathbf{8 b}$ suitable for X-ray analysis were grown by layering methylcyclohexane over the solution of $\mathbf{8 b}$ in $\mathrm{CH}_{2} \mathrm{Cl}_{2}$ at $-20^{\circ} \mathrm{C}$. The ORTEP diagram of $\mathbf{8 b}$ is shown in Figure 3. 
The bound ethylene $\mathrm{C}=\mathrm{C}$ bond length is $1.348(10) \AA$, which is slightly lenghthened compared to the $\mathrm{C}=\mathrm{C}$ distance of free ethylene $(1.337 \AA$ ), and falls within the values expected for silver-ethylene complexes. Less than 20 silver-ethylene complexes have been structurally characterized. ${ }^{4 a-c, 10,11}$ Among them, the only examples of cationic complexes are tris(ethylene) $\mathrm{Ag}$ cations reported by Dias and Krossing. ${ }^{4 \mathrm{a}-\mathrm{c}}$

\section{D. Synthesis and Properties of Gold Complex 9}

Well-characterized gold-ethylene adducts are particularly rare. Only six complexes appear to be characterized by X-ray crystallog raphy. ${ }^{3,4 \mathrm{~d}-\mathrm{f}, 12}$ Specifically, three fluorinated Tp$\mathrm{Au}$ (ethylene) complexes and one complex supported by a fluorinated triazapentadiene have been reported by Dias. ${ }^{3,4 f, 12}$ Two $\mathrm{Au}\left(\mathrm{C}_{2} \mathrm{H}_{4}\right)_{3}$ cationic complexes were structurally characterized by Dias and Krossing. ${ }^{4 \mathrm{~d}, \mathrm{e}}$ Cationic gold-ethylene complexes supported by nitrogen ligands have not been structurally characterized.

Complex 9 was synthesized by treating tris(ethylene)-gold hexafluoroantimonate ${ }^{4 \mathrm{~d}}$ with ligand 6 (Scheme 4). It was isolated in $42 \%$ yield as a dark red solid. Complex 9 decomposes in solution within an hour at room temperature. Therefore, it is imperative that 9 is prepared at low temperatures to obtain pure material. Solid 9 can be stored at $-20{ }^{\circ} \mathrm{C}$ under an inert atmosphere for several months. Crystals of $\mathbf{9}$ suitable for $\mathrm{X}$-ray analysis were grown by layering pentane over the solution of 9 in $\mathrm{CH}_{2} \mathrm{Cl}_{2}$ at $-20{ }^{\circ} \mathrm{C}$. The ORTEP diagram is shown in Figure 4.

The bound ethylene $\mathrm{C}=\mathrm{C}$ bond length is $1.455(13) \AA$, which is longer than the values observed for other structurally characterized Au-ethylene complexes at 1.351 to $1.387 \AA$. However, meaningful comparison of structures is difficult due to the scarcity of wellcharacterized gold-ethylene complexes.

\section{ETHYLENE SELF-EXCHANGE STUDIES}

\section{A. Copper Complex 7b}

Ligand exchange in 16-electron complexes usually proceeds by an associative substitution mechanism. ${ }^{13}$ A two-term rate law is often observed: rate $=k_{\text {obs }}$ [complex], where $k_{\text {obs }}=k_{1}$ $+k_{2}$ [ligand]. The $k_{1}$ term arises from associative substitution by solvent, counterion, or impurities. First, the mechanism of ethylene exchange was verified by the dependence of the bound ethylene ${ }^{1} \mathrm{H}$ NMR line shape on added free $\mathrm{C}_{2} \mathrm{H}_{4}$. Broadening of the complexed ethylene signal at 3.77-4.01 ppm was observed upon addition of ethylene, showing that ligand exchange is indeed associative.

Second, media-promoted ethylene loss $\left(k_{1}\right.$ term) was analyzed by variable-temperature ${ }^{1} \mathrm{H}$ NMR spectroscopy. For $C_{2}$-symmetric complex $\mathbf{7 b}$, the $k_{1}$ term can be determined by analysis of the complexed $\mathrm{C}_{2} \mathrm{H}_{4} \mathrm{AA}^{\prime} \mathrm{BB}^{\prime}$ system in the ${ }^{1} \mathrm{H}$ NMR spectrum that should collapse to a singlet upon media- promoted ethylene loss (followed by rapid reassociation). Thus, media-promoted ethylene loss in $\mathbf{7 b}$ was studied by variable-temperature ${ }^{1} \mathrm{H}$ NMR in $\mathrm{C}_{2} \mathrm{D}_{2} \mathrm{Cl}_{4}$. Data were analyzed by line shape analysis of the ethylene region of spectra. Firstorder rate constants $\left(k_{1 \mathrm{obs}}, \mathrm{s}^{-1}\right)$ were obtained by matching observed ${ }^{1} \mathrm{H}$ NMR spectra with those simulated using the WinDNMR program during coalescence of the bound ethylene 
signals. ${ }^{14}$ An Eyring analysis ${ }^{15}$ of the rate data between 303 and $373 \mathrm{~K}$ (see Supporting Information for details) gives $\Delta G_{298^{*}}=15.9 \pm 0.1 \mathrm{kcal} / \mathrm{mol}, \Delta H^{*}=9.9 \pm 0.2 \mathrm{kcal} / \mathrm{mol}$, and $\Delta S^{\dagger}=-20.1 \pm 1.5 \mathrm{eu}$. The negative value of the entropy of activation is consistent with associative ligand displacement. ${ }^{15}$

Third, ethylene exchange between the bound ethylene of $\mathbf{7 b}$ and free $\mathrm{C}_{2} \mathrm{H}_{4}$ was studied by variable-temperature ${ }^{1} \mathrm{H}$ NMR in $\mathrm{C}_{2} \mathrm{D}_{2} \mathrm{Cl}_{4}$. Ethylene was added to the solution of $\mathbf{7 b}$ via syringe, and the exact quantity of added $\mathrm{C}_{2} \mathrm{H}_{4}$ (8.8 equiv) was determined by integration of NMR signals. Matching the observed ${ }^{1} \mathrm{H}$ NMR spectra with those simulated using the WinDNMR program until coalescence of bound and free ethylene signals occurred gave first-order rate constants $\left(k_{2 \mathrm{obs}}, \mathrm{s}^{-1}\right)$. An Eyring analysis of the calculated second-order rate data between 256 and $304 \mathrm{~K}$ (see Supporting Information for details) gives $\Delta G_{298}{ }^{\ddagger}=12.9$ $\pm 0.1 \mathrm{kcal} / \mathrm{mol}, \Delta H^{\star}=6.2 \pm 0.5 \mathrm{kcal} / \mathrm{mol}$, and $\Delta S^{\dagger}=-22.5 \pm 1.7 \mathrm{eu}$. As expected, activation parameters are consistent with those expected for associative ligand displacement. The $k_{1}$ term for media-promoted ethylene exchange does not provide a significant contribution to $k_{\text {obs }}$ since $k_{1 \mathrm{obs}} \ll k_{2 \mathrm{obs}}$.

\section{B. Silver Complex 8a}

Free and complexed ethylene signals in $\mathbf{8 a}$ are coalesced into a sharp singlet at all temperatures above ca. $156 \mathrm{~K}$. However, at $146 \mathrm{~K}$ in $\mathrm{CDCl}_{2} \mathrm{~F}$ solvent some broadening can be observed as decoalescence appears to be beginning. An approximate upper limit of $\Delta G^{\natural}$ can be calculated at $146 \mathrm{~K}$ using the fast exchange approximation and assuming that the observed broadening of the coalesced signal is due to a slowed exchange rate. The upper limit of $\Delta G^{\natural}$, assuming associative ligand exchange by analogy with $\mathbf{7 b}$, was estimated to be ca. $5.0 \mathrm{kcal} / \mathrm{mol}$ (see Supporting Information for details). The number is approximate due to the following reasons. First, the equation used for equally populated sites was employed. Second, some broadening of other signals was also observed at $146 \mathrm{~K}$, indicating broadening could be due to other effects. Hence, the calculated $\Delta G^{\natural}$ value was considered as a higher limit of $\Delta G^{\dagger}$.

\section{C. Gold Complex 9}

Ethylene exchange between 9 and $\mathrm{C}_{2} \mathrm{H}_{4}$ is slow on the NMR time scale at temperatures up to $50^{\circ} \mathrm{C}$. At those and higher temperatures, complex 9 is unstable and decomposes to colloidal gold. Consequently, the exchange rate could not be determined by NMR linebroadening experiments. Complex 9- $d_{4}$ was prepared in $81 \%$ yield by purging a solution of 9 in $\mathrm{CH}_{2} \mathrm{Cl}_{2}$ with $\mathrm{C}_{2} \mathrm{D}_{4}$ at $-30{ }^{\circ} \mathrm{C} .{ }^{1} \mathrm{H}$ NMR analysis indicated $97 \%$ conversion to the labeled complex. An excess of $\mathrm{C}_{2} \mathrm{H}_{4}$ was added, the exact concentration of $\mathrm{C}_{2} \mathrm{H}_{4}$ was measured by NMR, and the rate of incorporation of unlabeled ethylene into 9 was monitored by ${ }^{1} \mathrm{H}$ NMR spectroscopy at 199, 204, 209, and $214 \mathrm{~K}$ (Table 1). An Eyring analysis of the rate data (Figure 5) gives $\Delta G_{298}+\frac{\ddagger}{\ddagger}=16.7 \pm 0.1 \mathrm{kcal} / \mathrm{mol}, \Delta H^{\dagger}=10.0 \pm 1.4 \mathrm{kcal} / \mathrm{mol}$, and $\Delta S^{\dagger}$ $=-22.5 \pm 4.8 \mathrm{eu}$. The negative value of the activation entropy is consistent with an associative ligand displacement mechanism. 


\section{DISCUSSION}

We have synthesized and characterized a complete set of group 11 metal complexes possessing the same "sandwich" diimine supporting ligand. Only a few such complete series of coinage metal complexes have been structurally characterized. Krossing and Dias have reported a series of $\mathrm{M}\left(\mathrm{C}_{2} \mathrm{H}_{4}\right)_{3}{ }^{+} \mathrm{X}^{-}$complexes, where $\mathrm{M}=\mathrm{Cu}, \mathrm{Ag}$, and $\mathrm{Au}$ and $\mathrm{X}^{-}=$ noncoordinating counterion. ${ }^{4 \mathrm{a}-\mathrm{e}}$ Bound ethylene $\mathrm{C}=\mathrm{C}$ bond lengths vary from 1.33 to 1.36 $\AA(\mathrm{M}=\mathrm{Cu})$ to $1.32-1.33 \AA(\mathrm{M}=\mathrm{Ag})$ to $1.364 \AA(\mathrm{M}=\mathrm{Au})$. Dias has disclosed complexes of the general structure $\left.\left[\mathrm{PhB}\left(3-\mathrm{C}_{2} \mathrm{~F}_{5}\right) \mathrm{Pz}\right)_{3}\right] \mathrm{M}\left(\mathrm{C}_{2} \mathrm{H}_{4}\right)$, where $\mathrm{M}=\mathrm{Cu}, \mathrm{Ag}$, and $\mathrm{Au} .{ }^{4 \mathrm{f}}$ In this series, $d_{\mathrm{C}=\mathrm{C}}$ for complexed ethylene is 1.354(7) $\AA(\mathrm{M}=\mathrm{Cu}), 1.311(5)(\mathrm{M}=\mathrm{Ag})$, and 1.366(12) $(\mathrm{M}=\mathrm{Au})$. For our series, bound ethylene $\mathrm{C}=\mathrm{C}$ bond distances are $1.346(8) \AA(\mathrm{M}$ $=\mathrm{Cu}), 1.348(10) \AA(\mathrm{M}=\mathrm{Ag})$, and 1.455(13) $\AA(\mathrm{M}=\mathrm{Au})$. The trend is the same for all three sets, with the greatest complexed ethylene $\mathrm{C}=\mathrm{C}$ bond lengthening observed for $\mathrm{Au}$ and the smallest for $\mathrm{Ag}$ and $\mathrm{Cu}$ complexes. Results are summarized in Table 2.

Furthermore, we have determined ethylene self-exchange energetics for complexes $\mathbf{7 b}, \mathbf{8 a}$, and 9. This study represents the first kinetic study of olefin exchange in isostructural coinage metal complexes. The ethylene self-exchange rate for Ag complex 8a is too fast to be measured even at $146 \mathrm{~K}$. Estimation of the upper limit of $\Delta G^{\dagger}$ gives a value of $5.0 \mathrm{kcal} / \mathrm{mol}$. In contrast, the corresponding values for copper and gold complexes $7 \mathbf{b}$ and $\mathbf{9}$ are $\Delta G_{298^{*}}=$ $12.9 \pm 0.1 \mathrm{kcal} / \mathrm{mol}, \Delta H^{*}=6.2 \pm 0.5 \mathrm{kcal} / \mathrm{mol}, \Delta S^{\ddagger}=-22.5 \pm 1.7 \mathrm{kcal} / \mathrm{mol}(7 \mathbf{b})$ and $\Delta G_{298}$ $=16.7 \pm 0.1 \mathrm{kcal} / \mathrm{mol}, \Delta H^{+}=10.0 \pm 1.4 \mathrm{kcal} / \mathrm{mol}, \Delta S^{\dagger}=-22.5 \pm 4.8 \mathrm{kcal} / \mathrm{mol}(9)$. The exchange rate shows the following trend: $\mathrm{Ag}$ (second transition series) $\gg \mathrm{Cu}$ (first transition series) $>\mathrm{Au}$ (third transition series).

Inspection of the literature shows several other cases where the ligand exchange rates follow the order $4 \mathrm{~d}$ metal $>3 \mathrm{~d}$ metal $>5 \mathrm{~d}$ metal. Carbon monoxide substitution by phosphine ligands in $\mathrm{CpM}(\mathrm{CO})_{2}(\mathrm{M}=\mathrm{Co}, \mathrm{Rh}, \mathrm{Ir})$ systems shows first-order kinetics for both the metal complex and incoming ligand, suggesting an associative substitution mechanism. ${ }^{16}$ The substitution rates follow the trend $\mathrm{Rh}>\mathrm{Co}>\mathrm{Ir}$. Interestingly, the tendency observed in $\mathrm{CpM}(\mathrm{CO})_{2}$ and "sandwich" diimine-coinage metal-ethylene complexes is consistent with two studies where dissociative ligand substitution was investigated. Nickel triad $\left[(\mathrm{EtO})_{3} \mathrm{P}\right]_{4} \mathrm{M}$ complexes show the fastest exchange for Pd and the slowest for Pt species, with the Ni complex demonstrating an intermediate substitution rate. ${ }^{17}$ Further more, substitution reactions of group VI metal hexacarbonyls show the fastest exchange rates for the molybdenum complex. ${ }^{18}$ Metal-ligand bond energies in 14-electron $\mathrm{M}\left(\mathrm{C}_{2} \mathrm{H}_{4}\right)_{2}{ }^{+}$species also follow the trend $\mathrm{Au}>\mathrm{Cu}>\mathrm{Ag} \cdot{ }^{19}$ Results obtained in our study provide another example of a case where the complex of the second transition series element shows the fastest ligand exchange rates.

\section{CONCLUSIONS}

We have synthesized and structurally characterized isostructural "sandwich" diiminecoinage metal ethylene complexes. Ethylene self-exchange kinetics in these complexes proceeds by an associative exchange mechanism for $\mathrm{Cu}$ and $\mathrm{Au}$ complexes. The fastest ligand exchange was observed for Ag complex 8a, where the exchange rate is too fast to be 
accurately measured even at $146 \mathrm{~K}$. Ethylene self-exchange in $\mathrm{Cu}$ complex $\mathbf{7 b}$ proceeds with $\Delta G_{298}{ }^{\ddagger}=12.9 \pm 0.1 \mathrm{kcal} / \mathrm{mol}$, while the exchange is the slowest in Au complex 9, with $\Delta G_{298}{ }^{\ddagger}=16.7 \pm 0.1 \mathrm{kcal} / \mathrm{mol}$. Copper complex $\mathbf{7 b}$ is unusually stable and can survive in air for years.

\section{Supplementary Material}

Refer to Web version on PubMed Central for supplementary material.

\section{Acknowledgments}

We thank the Welch Foundation (Chair E-0044) and NIGMS (Grant No. R01GM077635) for supporting this research, and Dr. George N. Oh for collecting diffraction data and solving the X-ray structure of $\mathbf{8 b}$. Additional Xray crystallography assistance by Sara N. Vandevelde is gratefully acknowledged. Low-temperature NMR studies of 8a were performed with the help of Dr. Steven K. Silber, and Prof. Maurice Brookhart is acknowledged for helpful discussions.

\section{References}

1. (a) Ittel SD, Johnson LK, Brookhart M. Chem Rev. 2000; 100:1169-1204. [PubMed: 11749263] (b) Brown JM. Organometallics. 2014; 33:5912-5923.(c) Love JA. Nat Chem. 2010; 2:524-525. [PubMed: 20571567]

2. (a) Mar Diaz-Requejo M, Perez PJ. J Organomet Chem. 2001; 617-618:110.(b) Mar Diaz-Requejo M, Perez PJ. Chem Rev. 2008; 108:3379-3394. [PubMed: 18698739] (c) Dias HVR, Lovely CJ. Chem Rev. 2008; 108:3223-3238. [PubMed: 18698738] (d) Dias HVR, Wu J. Eur J Inorg Chem. 2008; 2008:509-522.

3. Dias HVR, Wu J. Angew Chem Int Ed. 2007; 46:7814-7816.

4. (a) Fianchini M, Campana CF, Chilukuri B, Cundari TR, Petricek V, Dias HVR. Organometallics. 2013; 32:3034-3041.(b) Krossing I, Reisinger A. Angew Chem Int Ed. 2003; 42:5725-5728.(c) Reisinger A, Trapp N, Knapp C, Himmel D, Breher F, Rüegger H, Krossing I. Chem - Eur J. 2009; 15:9505-9520. [PubMed: 19693753] (d) Dias HVR, Fianchini M, Cundari TR, Campana CF. Angew Chem Int Ed. 2008; 47:556-559.(e) Schaefer J, Himmel D, Krossing I. Eur J Inorg Chem. 2013; 2013:2712-2717.(f) Dias HVR, Wu J. Organometallics. 2012; 31:1511-1517.

5. (a) Bainbridge MJ, Smith JRL, Walton PH. Dalton Trans. 2009:3143-3152. [PubMed: 19421616] (b) Ebrahimpour P, Haddow MR, Wass DF. Inorg Chem. 2013; 52:3765-3771. [PubMed: 23496261] (c) Suenaga Y, Wu LP, Kuroda-sowa T, Munakata M, Maekawa M. Polyhedron. 1997; 16:67-70.(d) Dai J, Yamamoto M, Kuroda-Sowa T, Maekawa M, Suenaga Y, Munakata M. Inorg Chem. 1997; 36:2688-2690.(e) Thompson JS, Whitney JF. Inorg Chem. 1984; 23:2813-2819.

6. Nadres ET, Santos GIF, Shabashov D, Daugulis O. J Org Chem. 2013; 78:9689-9714. [PubMed: 24090404]

7. (a) Vaidya T, Klimovica K, LaPointe A, Keresztes I, Lobkovsky E, Daugulis O, Coates G. J Am Chem Soc. 2014; 136:7213-7216. [PubMed: 24773453] (b) Allen KE, Campos J, Daugulis O, Brookhart M. ACS Catal. 2015; 5:456-464.(c) Zhang D, Nadres ET, Brookhart M, Daugulis O. Organometallics. 2013; 32:5136-5143.

8. (a) Munakata M, Kitagawa S, Kosome S, Asahara A. Inorg Chem. 1986; 25:2622-2627.(b) Thompson JS, Harlow RL, Whitney JF. J Am Chem Soc. 1983; 105:3522-3527.(c) Martín C, Muñoz-Molina JM, Locati A, Alvarez E, Maseras F, Belderrain TR, Pérez PJ. Organometallics. 2010; 29:3481-3489.(d) Dai X, Warren TH. Chem Commun. 2001:1998-1999.(e) Straub BF, Eisenträger F, Hofmann P. Chem Commun. 1999:2507-2508.(f) Dias HVR, Wang X, Diyabalanage HVK. Inorg Chem. 2005; 44:7322-7324. [PubMed: 16212357]

9. Connelly NG, Geiger WE. Chem Rev. 1996; 96:877-910. [PubMed: 11848774]

10. (a) Dias HVR, Fianchini M. Angew Chem Int Ed. 2007; 46:2188-2191.(b) Kou X, Dias HVR. Dalton Trans. 2009:7529-7536. [PubMed: 19727475] (c) Dias HVR, Wu J, Wang X, Rangan K. Inorg Chem. 2007; 46:1960-1962. [PubMed: 17309252] 
11. Chiong HA, Daugulis O. Organometallics. 2006; 25:4054-4057.

12. Flores JA, Dias HVR. Inorg Chem. 2008; 47:4448-4450. [PubMed: 18433091]

13. Hartwig, J., editor. Organotransition Metal Chemistry. University Science Books; Sausalito: 2010.

14. The DNMR simulations were performed with an updated version of WINDNMR (http:// www.chem.wisc.edu/areas/reich/plt/windnmr.htm)Reich HJ. WinDNMR Dynamic NMR Spectra for Windows. J Chem Educ. 1996; 3D(2):1086.doi: 10.1021/ed072p1086.1

15. Anslyn, EV.; Dougherty, DA., editors. Modern Physical Organic Chemistry. University Science Books; Sausalito: 2006.

16. Schuster-Woldan HG, Basolo F. J Am Chem Soc. 1966; 88:1657-1663.

17. Meier M, Basolo F, Pearson RG. Inorg Chem. 1969; 8:795-801.

18. Dobson GR. Acc Chem Res. 1976; 9:300-306.

19. Tai HC, Krossing I, Seth M, Deubel DV. Organometallics. 2004; 23:2343-2349. 

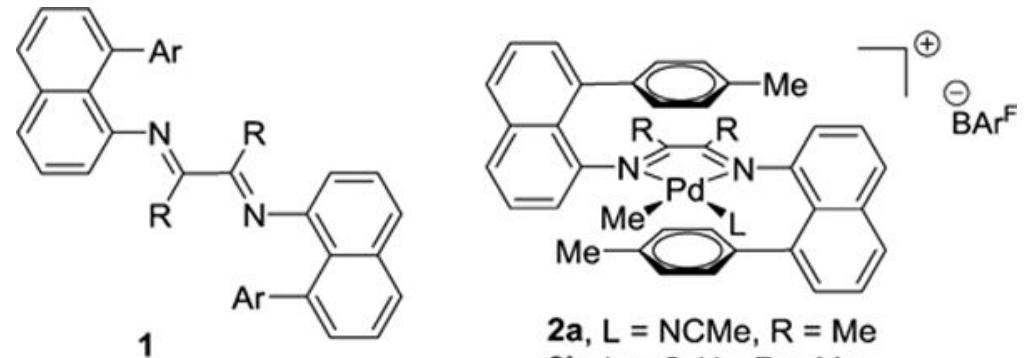

2a, $\mathrm{L}=\mathrm{NCMe}, \mathrm{R}=\mathrm{Me}$

2b, $\mathrm{L}=\mathrm{C}_{2} \mathrm{H}_{4}, \mathrm{R}=\mathrm{Me}$

Figure 1.

"Sandwich" Diimine Ligands and Their Palladium Complexes. 


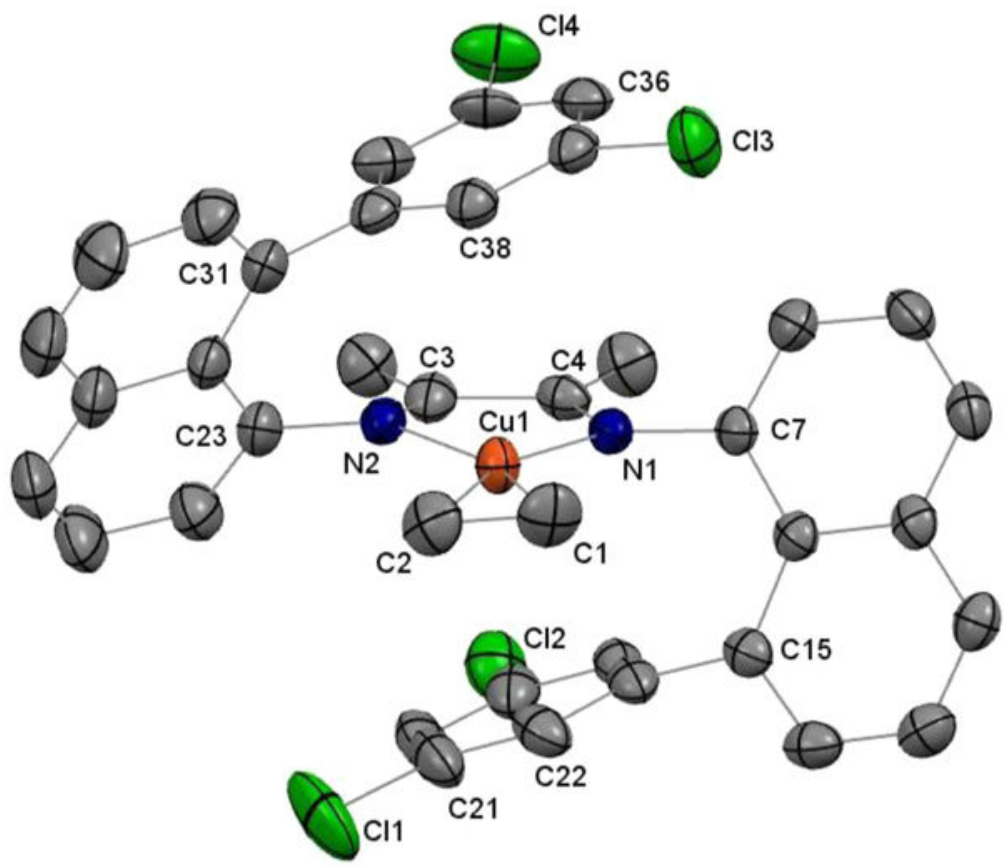

Figure 2.

ORTEP view of the molecular structure of 7a. Thermal ellipsoids are drawn to encompass $50 \%$ probability. Hydrogens and the triflate counterion are omitted for clarity. Selected bond distances $(\AA)$ and angles $(\mathrm{deg})$ : $\mathrm{C}(1)-\mathrm{C}(2)$ 1.346(8), $\mathrm{Cu}(1)-\mathrm{C}(1) 2.016(5), \mathrm{Cu}(1)-\mathrm{C}(2)$ 1.972(5), $\mathrm{Cu}(1)-\mathrm{N}(1) 1.970(4), \mathrm{Cu}(1)-\mathrm{N}(2)$ 1.986(4), N(1)-Cu(1)-N(2) 81.94(16). 


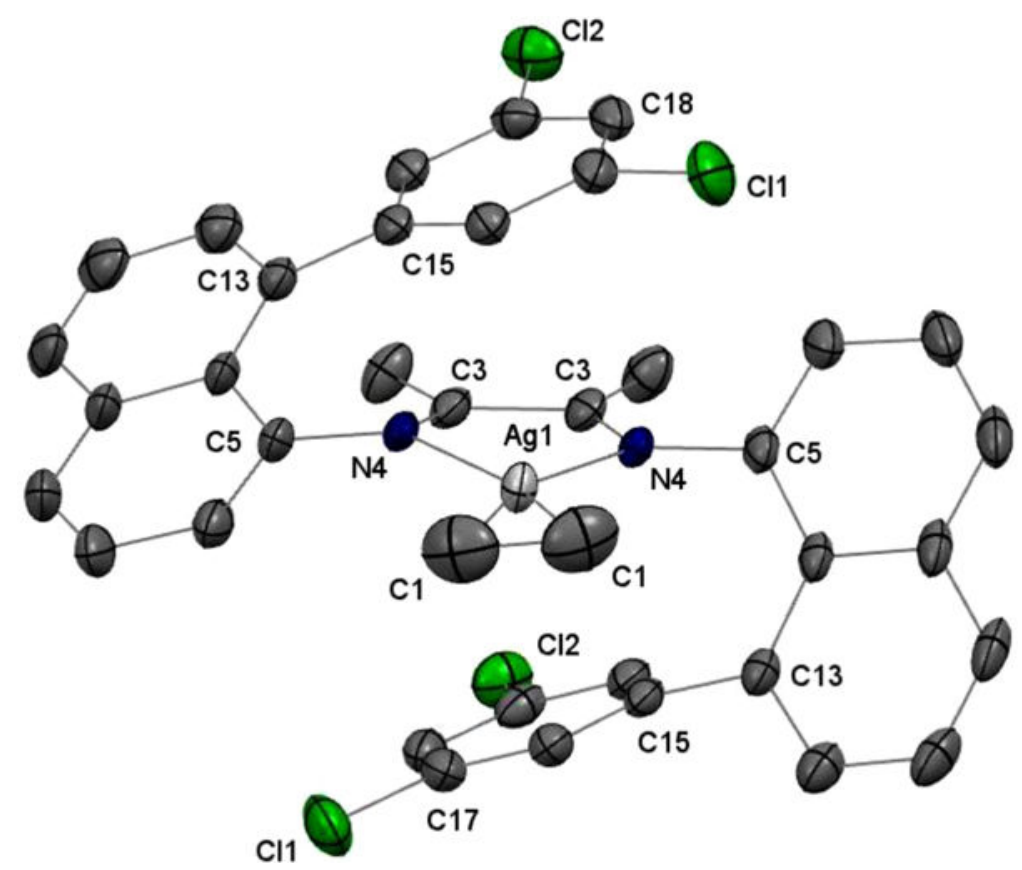

Figure 3.

ORTEP view of the molecular structure of $\mathbf{8 b}$. Thermal ellipsoids are drawn to encompass $50 \%$ probability. Hydrogens, $\mathrm{CH}_{2} \mathrm{Cl}_{2}$, methylcyclohexane, and the tetrafluoroborate counterion are omitted for clarity. Selected bond distances $(\AA)$ and angles (deg): C(1)-C(1) 1.348(10), $\mathrm{Ag}(1)-\mathrm{C}(1)$ 2.237(4), $\mathrm{Ag}(1)-\mathrm{N}(4)$ 2.241(3), N(4)-Ag(1)-N(4) 72.46(13). 


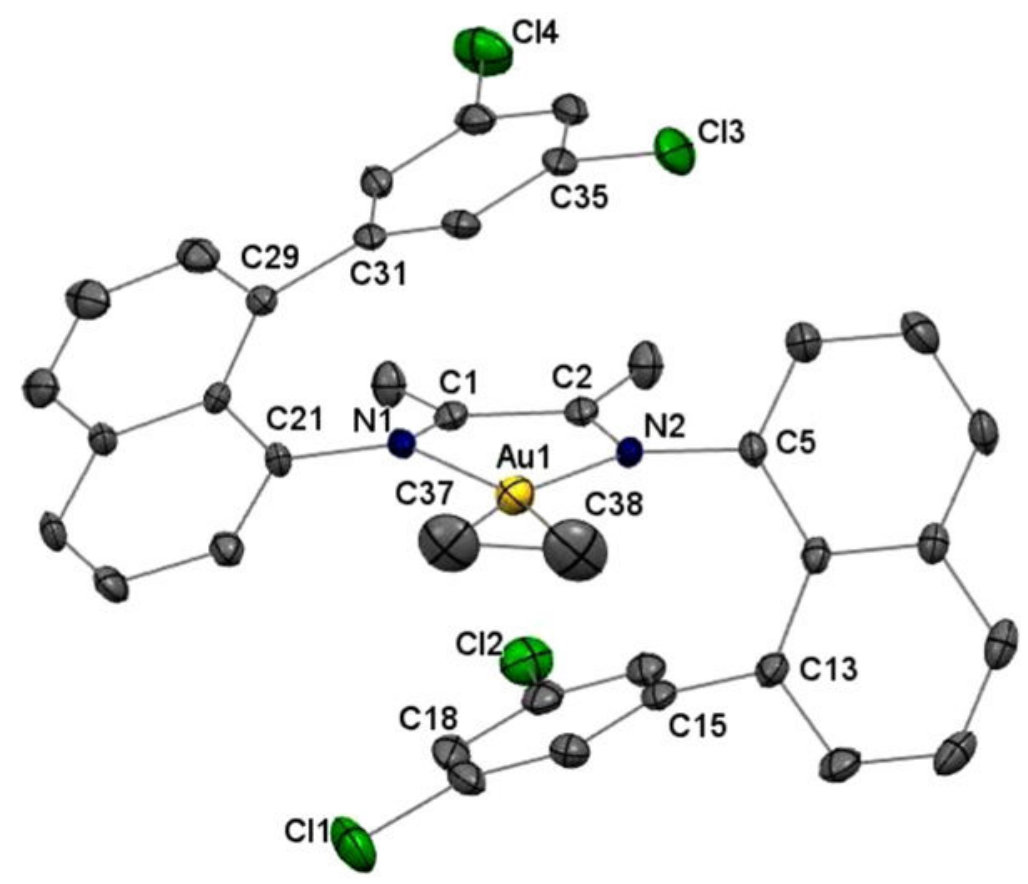

Figure 4.

ORTEP view of the molecular structure of 9. Thermal ellipsoids are drawn to encompass $50 \%$ probability. Hydrogens and the hexafluoroantimonate counterion are omitted for clarity. Selected bond distances ( $\mathrm{A})$ and angles (deg): C(37)-C(38) 1.455(13), Au(1)-C(37)

2.118(8), Au(1)-C(38) 2.094(8), Au(1)-N(1) 2.199(5), Au(1)-N(2) 2.196(5), N(2)-Au(1)$\mathrm{N}(1) 73.16(18)$. 

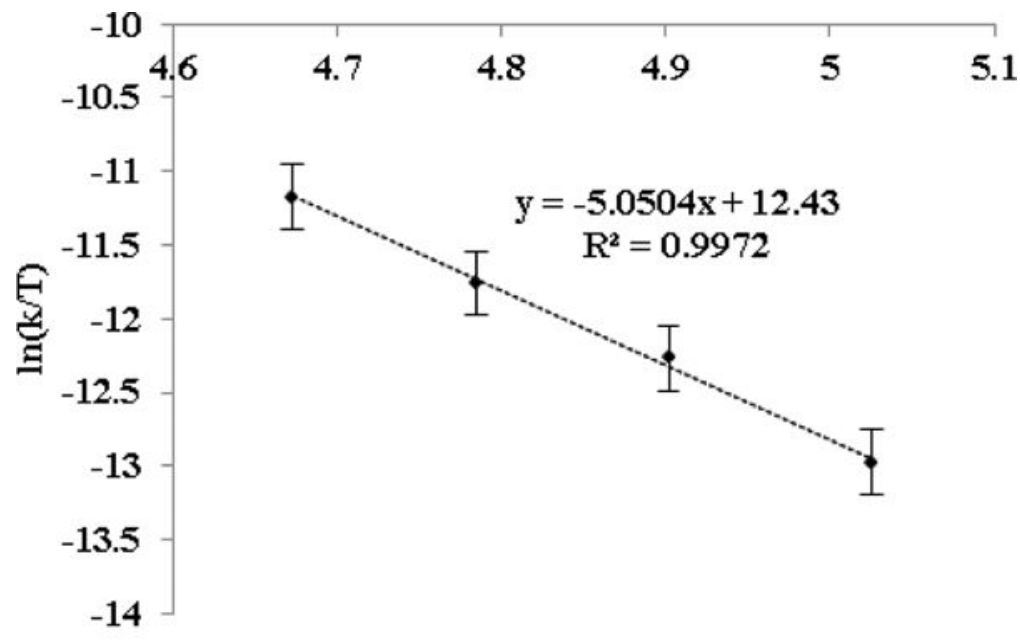

$1000 / \mathrm{T}$

Figure 5.

Eyring plot for ethylene exchange in 9- $d_{4}$. 


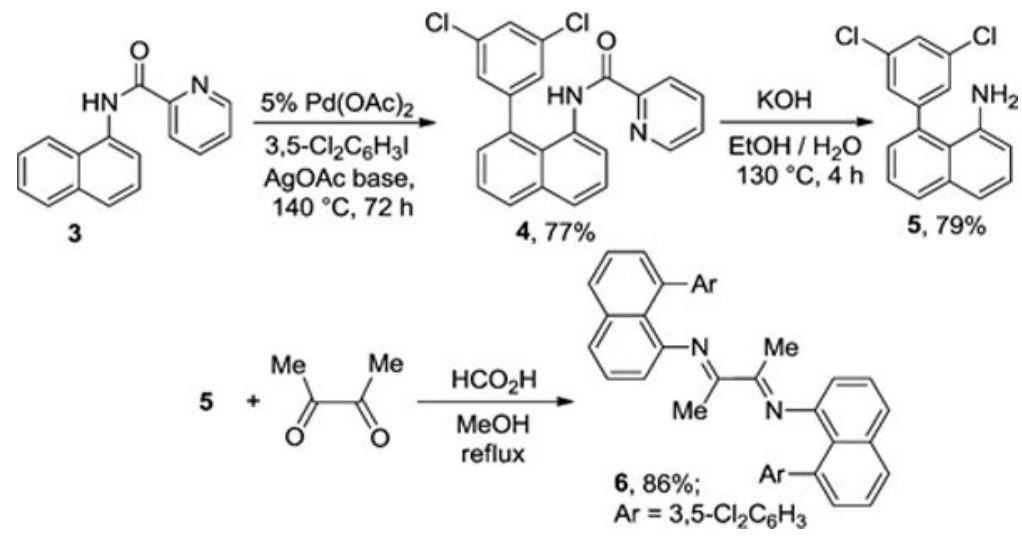

Scheme 1.

Synthesis of Diimine Ligand 6 


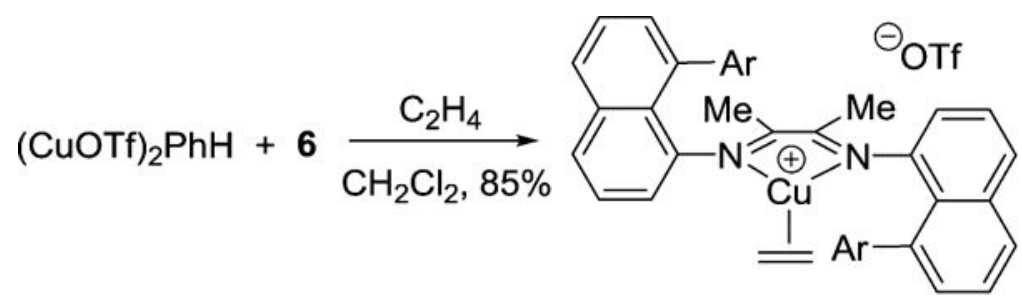

7a, $\mathrm{Ar}=3,5-\mathrm{Cl}_{2} \mathrm{C}_{6} \mathrm{H}_{3}$

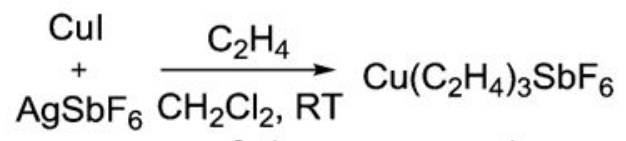
ref. $4 a$

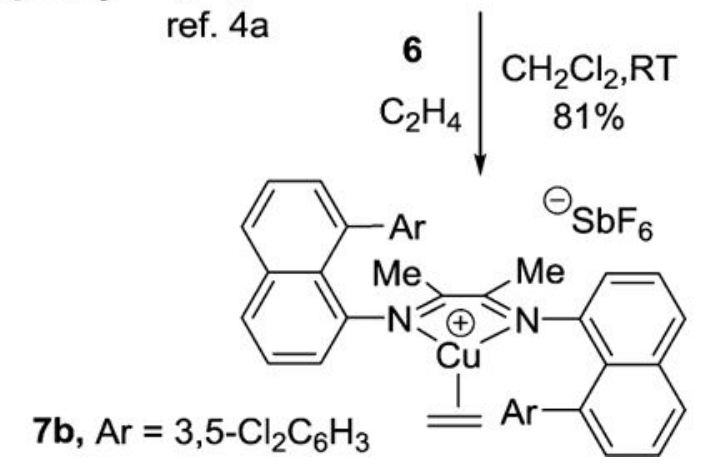

Scheme 2.

Synthesis of Copper Complexes 7a and 7b 


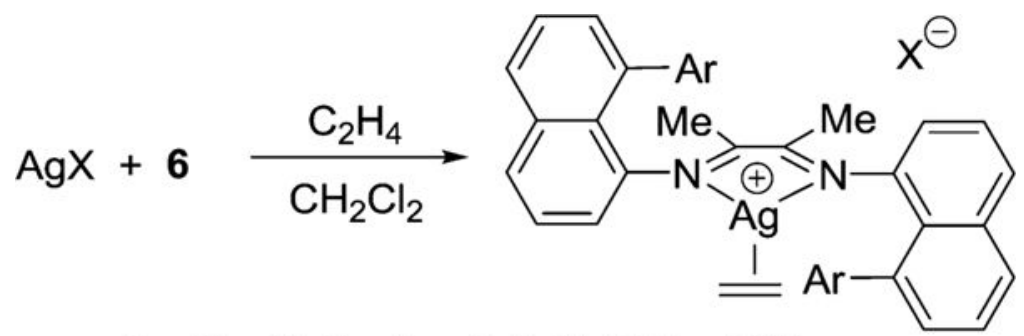

8a, $X=\mathrm{SbF}_{6}, \mathrm{Ar}=3,5-\mathrm{Cl}_{2} \mathrm{C}_{6} \mathrm{H}_{3}, 78 \%$

$\mathbf{8 b}, \mathrm{X}=\mathrm{BF}_{4}, \mathrm{Ar}=3,5-\mathrm{Cl}_{2} \mathrm{C}_{6} \mathrm{H}_{3}, 88 \%$

Scheme 3.

Synthesis of Silver Complexes $8 \mathrm{a}$ and $8 \mathrm{~b}$ 
$\underset{+\mathrm{AgSbF}}{\stackrel{\mathrm{AuCl}}{\mathrm{AH}_{6}}} \underset{\mathrm{CH}_{2} \mathrm{Cl}_{2}, \mathrm{RT}}{\stackrel{\mathrm{C}_{2} \mathrm{H}_{4}}{\longrightarrow}} \mathrm{Au}\left(\mathrm{C}_{2} \mathrm{H}_{4}\right)_{3} \mathrm{SbF}_{6}$

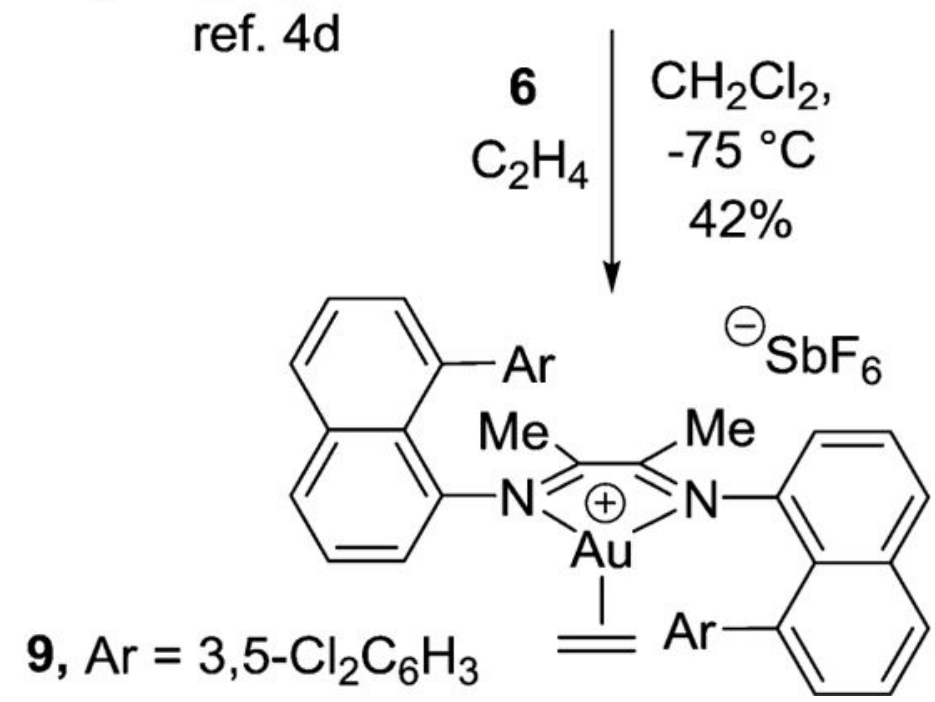

Scheme 4.

Synthesis of Gold Complex 9 


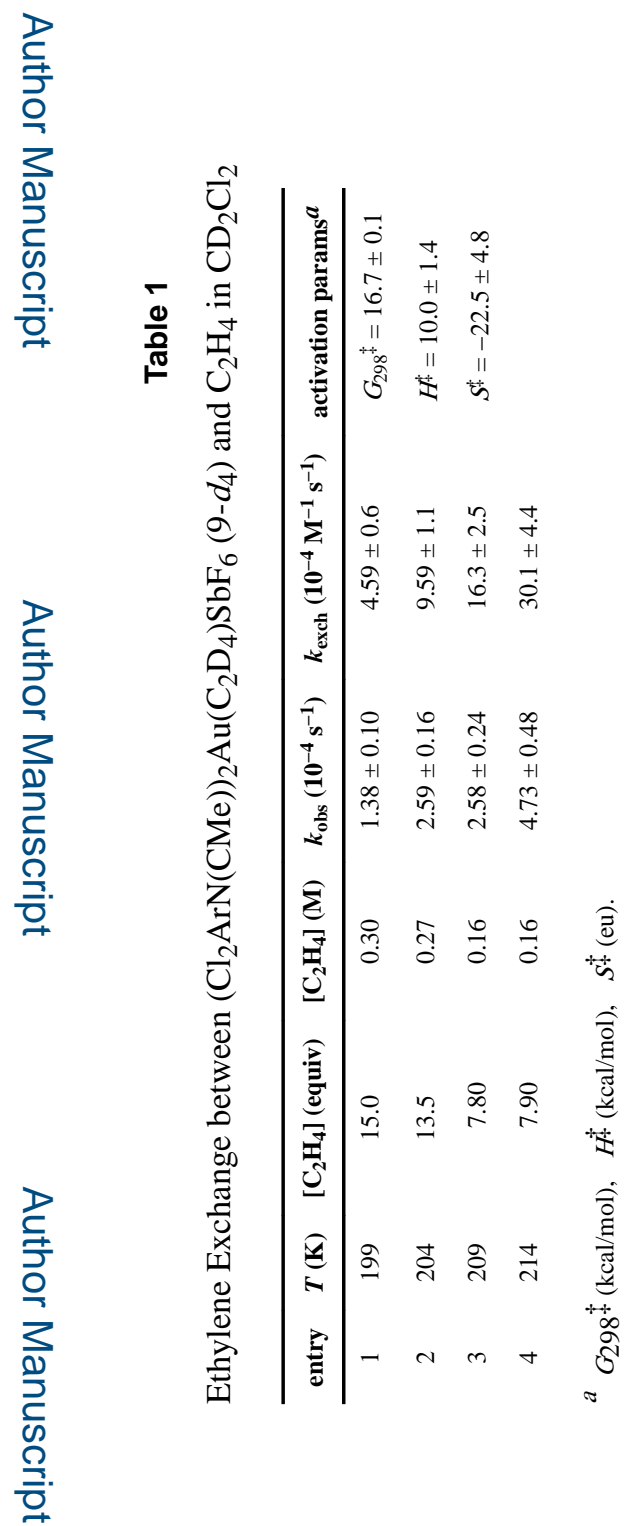

Organometallics. Author manuscript; available in PMC 2017 September 12. 


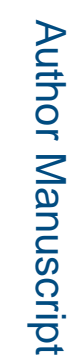

ᄅ⿳亠口冋口

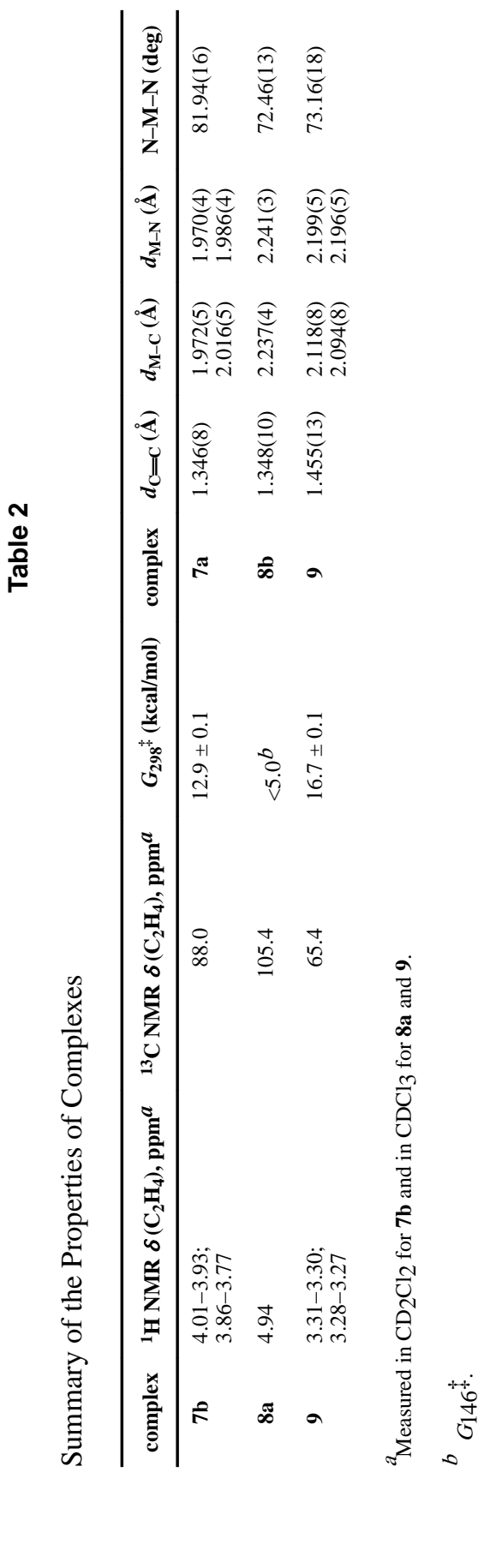

Organometallics. Author manuscript; available in PMC 2017 September 12. 